\title{
A Functional Integrin Ligand on the Surface of Platelets: Intercellular Adhesion Molecule-2
}

Thomas G. Diacovo, Antonin R. deFougerolles, ${ }^{*}$ Dorothy F. Bainton, ${ }^{\star}$ and Timothy A. Springer

Harvard Medical School, Division of Newborn Medicine, Boston, Massachusetts 02115; *Wellcome Trust Immunology Unit, University of Cambridge, School of Clinical Medicine, Cambridge, United Kingdom CB2 2SP; and ${ }^{\ddagger}$ University of California-San Francisco,

Department of Pathology, San Francisco, California 94143-0506

\begin{abstract}
Activated platelets express P-selectin and release leukocyte chemoattractants; however, they have not been known to express integrin ligands important in the stabilization of leukocyte interactions with the vasculature. We now demonstrate the presence of intercellular adhesion molecule-2 (ICAM-2) (CD102), and lack of expression of other $\beta_{2^{-}}$ integrin ligands, ICAM-1 (CD54) and ICAM-3 (CD50), on the surface of resting and stimulated platelets. ICAM-2 isolated from platelets migrates as a band of $59,000 M_{r}$ in reducing sodium dodecyl sulfate-polyacrylamide gel electrophoresis. Staining of bone marrow aspirates with antiICAM-2 mAb demonstrates strong reactivity to megakaryocytes. Using frozen thin sections and immunogold labeling, the antigen was shown to be present on the plasma membrane and surface-connected canalicular system of resting platelets. The average number of ICAM-2 molecules per platelet is $3,000 \pm 230$ and does not change after activation. In adhesion assays, resting and stimulated platelets were capable of binding through ICAM-2 to purified leukocyte function-associated antigen-1. Activation of $T$ lymphocytes with PMA stimulated binding to platelets that was $\mathbf{M g}^{2+}$ dependent and could be specifically inhibited by mAbs to either ICAM-2 or leukocyte function-associated antigen-1. ICAM-2 is the only known $\beta_{2}$-integrin ligand present on platelets, suggesting that it may play an important role in leukocyte-platelet interactions in inflammation and thrombosis. (J. Clin. Invest. 1994. 94:1243-1251.) Key words: CD102 • megakaryocyte • LFA-1 • CD11a/CD18
\end{abstract}

\section{Introduction}

Platelets play a central role in hemostasis involving complex interactions among these cells, leukocytes, and the injured vessel wall. Adhesion of platelets to exposed subendothelium requires the concerted actions of extracellular matrix components, the integrin family of adhesion receptors, and glycoprotein $\mathrm{Ib}$ $(1,2)$. These molecules, in conjunction with the contents of alpha granules and dense granules released during platelet acti-

Address correspondence to Timothy Springer, The Center for Blood Research, 200 Longwood Avenue, Boston, MA 02115.

Received for publication 20 December 1993 and in revised form 2 May 1994.

J. Clin. Invest.

(c) The American Society for Clinical Investigation, Inc.

0021-9738/94/09/1243/09 \$2.00

Volume 94, September 1994, 1243-1251 vation, serve to recruit and aggregate additional platelets to the site of vascular injury. Human platelets express at least five integrins which recognize extracellular matrix proteins such as collagen $\left(\alpha^{2} \beta_{1}\right)$, fibronectin $\left(\alpha^{5} \beta_{1}\right)$, laminin $\left(\alpha^{6} \beta_{1}\right.$, fibrinogen $\left(\alpha^{\mathrm{Ib}} \beta_{3}\right)$, and vitronectin $\left(\alpha^{\mathrm{v}} \beta_{3}\right)(3,4)$; none are known to be primarily involved in platelet-leukocyte interactions.

The recruitment of leukocytes from the blood, essential for inflammation and the immune response, is an active process requiring at least three sequential events. The initial interaction ( step 1) is mediated by the selectin family of molecules and their oligosaccharide ligands, an event that is both transient and reversible. Subsequent stabilization of leukocyte-endothelial interactions requires both the activation of leukocyte adhesion molecules by specific chemoattractants (step 2) and binding of integrins on leukocytes to counterreceptors on the vascular wall (step 3). Participants in the first two of these steps have been defined on platelets. P-selectin, an integral membrane protein translocated to the surface of activated platelets $(5,6)$, has been shown to interact specifically with leukocytes under flow conditions $(7,8)$. Platelets also release several leukocyte chemoattractants after activation, including RANTES, and platelet basic protein that is converted to neutrophil activating peptide$2(9,10)$. The presence of an integrin ligand, important in the third step of the adhesion process, has not been identified on platelets. CD31, a member of the immunoglobulin superfamily that is expressed on platelets, leukocytes, and endothelium, has been suggested as a possible candidate, but has not been demonstrated to mediate platelet-leukocyte adhesion (11). Another study has provided evidence for recognition by $\beta_{2}$-integrins of a counter-structure on platelets that appears to be involved in adhesion (12).

Understanding the different steps involved in platelet-leukocyte interactions requires that the identity of all the adhesive ligands be established. Therefore, we have evaluated the presence of intercellular adhesion molecules (ICAMs) ${ }^{1}$ on the surface of resting and activated platelets. We present evidence that ICAM-2, and not ICAM-1 or ICAM-3, is present on the surface of resting and activated platelets. This $\beta_{2}$-integrin ligand is constitutively expressed on platelets and has a molecular weight similar to that found previously on vascular endothelium and certain T cell lines (13). Furthermore, ICAM-2 on platelets is capable of supporting adhesion to purified leukocyte functionassociated antigen-1 (LFA-1) and to LFA-1 on activated T lymphocytes. ICAM-2 is the first ligand for an integrin to be described on the platelet surface.

1. Abbreviations used in this paper: ICAM, intercellular adhesion molecule; LFA, leukocyte function-associated antigen; RT, room temperature; SCCS, surface connected canalicular system. 


\section{Methods}

Preparation of platelets. Blood was obtained from healthy donors and was diluted 9:1 with acid-citrate-dextrose ( $85 \mathrm{mM}$ trisodium citrate, 69 $\mathrm{mM}$ citric acid, $111 \mathrm{mM}$ glucose, $\mathrm{pH} 4.6$ ) and $50 \mathrm{ng} / \mathrm{ml}$ prostaglandin $\mathrm{E}_{1}$ ( $\mathrm{PGE}_{1}$; Sigma Immunochemicals, St. Louis, $\mathrm{MO}$ ). Platelet-rich plasma, prepared by centrifugation of the blood at $180 \mathrm{~g}$ for $15 \mathrm{~min}$, was applied to a Sepharose CL-2B column (14) (Pharmacia LKB Biotechnology Inc., Piscataway, NJ) equilibrated with Hepes buffer ( $145 \mathrm{mM} \mathrm{NaCl}$, $10 \mathrm{mM}$ Hepes, $0.5 \mathrm{mM} \mathrm{Na}_{2} \mathrm{HPO}_{4}, 5 \mathrm{mM} \mathrm{KCl}, 2 \mathrm{mM} \mathrm{MgCl}, 0.1 \%$ glucose, $\mathrm{pH}$ 7.4). Platelets collected in the excluded volume were either left in the resting state or stimulated with human thrombin (Sigma Immunochemicals, St. Louis, MO) at a final concentration of $0.2 \mathrm{U} / \mathrm{ml}$ for $5 \mathrm{~min}$ at room temperature (RT). In all experiments, the activation status of resting and activated platelets was confirmed with $\mathrm{mAb}$ to $\mathrm{P}$ selectin and immunofluorescence flow cytometry. If fixation was required, an equal volume of $2 \%$ paraformaldehyde in Hepes buffer was added to the platelet suspensions, and the mixture was allowed to incubate at $37^{\circ} \mathrm{C}$ for $1 \mathrm{~h}$. The samples were then washed twice in Hepes buffer and resuspended at a concentration of $1-2 \times 10^{8} / \mathrm{ml}$. Platelet counts were performed on a cell counter $(\mathrm{H} 1$; Technicon Instruments Corp., Tarrytown, NY) and showed $<0.1 \%$ contamination with leukocytes or erythrocytes. All samples were used within $2 \mathrm{~h}$ of purification.

Monoclonal antibodies. The following previously described murine mAbs to human antigens were used: RR1/1 (anti-ICAM-1, IgG1) (15), CBR-IC2/1 (anti-ICAM-2, IgG2a) (13), CBR-IC2/2 (antiICAM-2, IgG2a) (13), CBR-IC3/1 (anti-ICAM-3, IgG1) (16), TS1/ 22 (anti-CD11a, IgG1) (17), and TS2/9 (anti-LFA-3, IgG1) (17) were produced in our laboratory. B1 (anti-CD20, IgG2a) (18), MY4 (anti-CD14, IgG2b) (19), and T3 (anti-CD3, IgG1 ) (20) were obtained from Coulter Immunology (Hialeah, FL). The mAb 3G8 (anti-CD16, IgG1 ) (21) was obtained from Amac, Inc. (Westbrook, ME). TP1/15 (anti-CD31, IgG2a), 7E1 (anti-CD41, IgG1) (22), and S12 (antiCD62, IgG1) (23) were obtained from the Fifth International Workshop on Human Leukocyte Differentiation Antigens. 187.1 mAb is an IgG rat anti-mouse kappa chain (24). All mAbs, either dilutions of ascites (1:200) or purified IgG $(10 \mu \mathrm{g} / \mathrm{ml})$, were used at saturating conditions. In addition, all experiments included irrelevant isotype-specific IgG mAbs as negative controls.

Flow cytometry. Monodispersed suspensions of paraformaldehyde fixed or unfixed resting and thrombin-stimulated platelets were prepared and used within $2 \mathrm{~h}$. Cells $\left(50 \mu \mathrm{l}\right.$ at $\left.1.0-2.0 \times 10^{8} / \mathrm{ml}\right)$ were added to U-bottom microtiter plates (Linbro-Titertek Flow Labs, McLean, VA) containing $50 \mu \mathrm{l}$ of the appropriate $\mathrm{mAb}$. After a 30-min incubation at RT, the cells were pelleted $(900 \mathrm{~g}, 3 \mathrm{~min}$, RT), washed with L15 medium containing $2.5 \%$ FCS and $2.0 \mathrm{mM}$ EDTA, and subsequently incubated with $30 \mu \mathrm{l}$ of a 1:20 dilution of FITC-labeled goat antimouse $F\left(a^{\prime}\right)_{2} \operatorname{Ig}$ (Zymed Laboratories, Inc., South San Francisco, CA) for $30 \mathrm{~min}$ at RT. The platelets were then rewashed, and the samples were analyzed using a FACScan ${ }^{\circledR}$ flow cytometer (Becton Dickinson Immunocytometry Systems, Mountain View, CA).

Surface iodination. Surface labeling of cells with ${ }^{125}$ I was performed by the method of Tuszynski et al. (25) using Iodogen (Pierce, Rockford, IL). Platelets were labeled with ${ }^{125}$ I ( $200 \mu \mathrm{Ci} \mathrm{Na}{ }^{125}$ I; Amersham Corp., Arlington Heights, IL) and lysed for $30 \mathrm{~min}$ at $4^{\circ} \mathrm{C}$ in $1 \mathrm{ml}$ of lysis buffer $(10 \mathrm{mM}$ Tris/HCl, pH 8.0, $150 \mathrm{mM} \mathrm{NaCl}, 1 \%$ Triton X-100, $1 \%$ hemoglobin, $1 \mathrm{mM}$ iodoacetamide, $1 \mathrm{mM}$ PMSF, $0.24 \mathrm{TIU} / \mathrm{ml}$ aprotinin, $0.025 \% \mathrm{NaN}_{3}$ ). Insoluble cellular debris was removed by centrifugation at $14,000 \mathrm{~g}$ for $20 \mathrm{~min}$, and the lysate was precleared overnight at $4^{\circ} \mathrm{C}$ with $100 \mu \mathrm{l}$ of packed bovine IgG coupled-Sepharose. Lysate $(100 \mu \mathrm{l})$ was then incubated with either control $\mathrm{mAb}$ or antiICAM-2 along with $187.1 \mathrm{mAb}$ for $1 \mathrm{~h}$ at $4^{\circ} \mathrm{C}(26)$. The antigenantibody complex was then precipitated with $50 \mu \mathrm{l}$ of protein A-Sepharose (Sigma Immunochemicals) and then briefly centrifuged at 14,000 g. The beads were washed three times in $25 \mathrm{mM}$ Tris/ $\mathrm{HCl}, \mathrm{pH} 8.0,150$ $\mathrm{mM} \mathrm{NaCl}, 0.1 \%$ Triton X-100, twice in $25 \mathrm{mM}$ Tris/HCl, $\mathrm{pH} 8.0,150$ $\mathrm{mM} \mathrm{NaCl}$, and once in $50 \mathrm{mM}$ Tris/ $\mathrm{HCl}, \mathrm{pH}$ 8.0. The beads were then treated with an equal volume of $2 \times$ SDS-PAGE sample buffer, heated to $100^{\circ} \mathrm{C}$ for $2 \mathrm{~min}$, and subjected to SDS $8 \%$ PAGE (27). Proteins were visualized with intensifying screens for $3 \mathrm{~d}$.

Labeling of proteins. Purified mAb to ICAM-2 was radioiodinated with $\mathrm{Na}^{125} \mathrm{I}(10 \mu \mathrm{Ci} / \mu \mathrm{g} \mathrm{mAb})$ using Iodogen and stored in PBS at $4^{\circ} \mathrm{C}$ (28). The labeled $\mathrm{mAb}$ was used in quantitative binding studies within 2 wk.

Binding experiments. A direct solution-phase saturation assay was used to evaluate ${ }^{125}$ I-labeled anti-ICAM-2 binding to unfixed gel-filtered platelets. Resting or activated platelets $\left(50 \mu \mathrm{l}, 1.5-2.0 \times 10^{8}\right.$ cells $/ \mathrm{ml}$ ) were incubated with $50 \mu \mathrm{l}$ radiolabeled $\mathrm{mAb}$ at varying concentrations for $2 \mathrm{~h}$ at RT. The free and platelet-bound antibodies were separated by centrifugation through a 1:9 ( vol/vol) Apiezon oil A/ $n$ butyl phthalate mixture (29) and ${ }^{125}$ I-labeled ICAM-2 antibody binding was measured in a Beckman Gamma 8000 spectrometer (Beckman Instruments, Inc., Fullerton, CA). Nonspecific binding was determined in the presence of a 100 -fold excess of unlabeled $\mathrm{mAb}$ and was subtracted from total binding to yield the specific binding. The number of binding sites per platelet was determined according to Scatchard (30).

Immunohistochemistry. Bone marrow smears, performed for evaluation of idiopathic thrombocytopenia, were obtained with the permission of The Children's Hospital (Boston, MA). They were air-dried and subsequently fixed for $90 \mathrm{~s}$ in acetone/methanol $/ 40 \%$ formalin (19:19:2). The primary antibody, anti-ICAM-2, was used at dilutions of 1:50 to 1:500. Subsequent steps were performed using reagents from the Dako APAAP kit for mouse monoclonal antibodies (Dako Corp., Carpinteria, CA). The substrate solution contained levamisole to inhibit endogenous alkaline phosphatase. Smears were counter-stained in Gill's hematoxylin and mounted in aqueous medium. For electron microscopy, citrated blood was dripped into a beaker containing $90 \mathrm{ml}$ of fixative (4\% paraformaldehyde in McLean and Nakane's buffer [31]) for $1 \mathrm{~h}$. The mixture was spun at $150 \mathrm{~g}$ for $20 \mathrm{~min}$ at $20^{\circ} \mathrm{C} \mathrm{(32).} \mathrm{The} \mathrm{pellet}$ was embedded in $2.1 \mathrm{M}$ sucrose, frozen, and stored in liquid nitrogen. Frozen thin sections were cut as previously described (33-35). The primary antibody, ICAM-2, was used at a dilution of 1:200, followed by rabbit anti-mouse Ig (Zymed Laboratories, Inc.) as a bridge (1:100). This was followed by the gold label, protein A-10, obtained from the Department of Cell Biology, University of Utrecht (Utrecht, The Netherlands), at 1:50 dilution. The grids were then stained with uranyl acetate and embedded in methyl cellulose. A nonbinding control $\mathrm{mAb}$ was also tested.

Cell adhesion assays. Immunoaffinity purified LFA-1 (36) was diluted $1: 10$ or $1: 20$ (20 mM Tris/ $\mathrm{HCl}, \mathrm{pH} 8.0,150 \mathrm{mM} \mathrm{NaCl}, 2 \mathrm{mM}$ $\mathrm{MgCl}_{2}[\mathrm{TSM}]$ ) and absorbed to either $60-\mathrm{mm}$ polystyrene Petri dishes ( $50 \mu \mathrm{l}$ demarcated spot) or 96-well microtiter plates $(50 \mu \mathrm{l})$ for $2 \mathrm{~h}$ at RT. LFA-1 purified in this manner is constitutively active and capable of binding to its ligands. Nonspecific binding sites were blocked with two washes and on incubation in TSM, $1 \%$ human serum albumin for $2 \mathrm{~h}$ at RT. Binding was assayed with resting or thrombin stimulated gel-filtered platelets resuspended in Hepes buffer to a final concentration of $1.5 \times 10^{8}$ cells $/ \mathrm{ml}$. For Petri dish assays, $2 \mathrm{ml}$ of unstimulated platelets was added to the dishes and incubated for $30 \mathrm{~min}$ at $37^{\circ} \mathrm{C}$. During the incubation period, the platelet suspension was gently agitated on an orbital shaker at $35 \mathrm{rpm}$. In addition, mAb pretreatment of cells or purified protein consisted of incubation with $20 \mu \mathrm{g} / \mathrm{ml}$ of either control antibody, anti-ICAM-2, or anti-LFA-1 monoclonal antibodies. Unbound platelets were removed by four successive washes with $1 \mathrm{ml}$ of Hepes buffer. Subsequently, binding was evaluated by light microscopy, and photographs were taken using a Zeiss microscope with phasecontrast optics.

For the 96-well plate assays, platelets were resuspended in $2 \mathrm{ml}$ of Hepes buffer containing $2 \mathrm{mM}$ RGDS (Arg-Gly-Asp-Ser) (Peninsula Laboratories, Inc., Belmont, CA) and labeled with $10 \mu \mathrm{g} / \mathrm{ml}$ of $2^{\prime}, 7^{\prime}-$ bis-(2-carboxyethyl)-5 (and-6) carboxyfluorescein (Molecular Probes, Inc., Eugene, OR) for $30 \mathrm{~min}$ at $37^{\circ} \mathrm{C}$. After washing twice, the platelets were resuspended in Hepes buffer at a concentration of $2 \times 10^{8}$ cells/ $\mathrm{ml}$. mAb pretreatment of the cells was performed as described above 
followed by the addition of $50 \mu \mathrm{l}$ of platelet suspension to the wells The plates were then briefly centrifuged $\left(900 \mathrm{~g}, 3 \mathrm{~min}, 37^{\circ} \mathrm{C}\right)$ and incubated at $37^{\circ} \mathrm{C}$ for $30 \mathrm{~min}$. The wells were washed six times by adding $200 \mu \mathrm{l}$ of binding buffer and aspirating with a 23-gauge needle. Fluorescence was directly quantitated from the 96-well plates using a Pandex fluorescence concentration analyzer (Baxter Healthcare Corp., Mundelein, IL).

Purification of $T$ lymphocytes. Human PBMC were isolated from citrate-anticoagulated whole blood after dextran sedimentation and density separation over Ficoll-Hypaque (37). Purified T lymphocytes were prepared from PBMC by negative selection using magnetic cell sorting, as described $(38,39)$. Briefly, PBMC were resuspended to a concentration of $1 \times 10^{7} / \mathrm{ml}$ in PBS, $1 \%$ BSA, and $5 \mathrm{mM}$ EDTA, pH 7.4 (PBE). Then, the cells were incubated with a mixture of $\mathrm{mAb}(5 \mu \mathrm{g} / \mathrm{ml})$ capable of reacting with monocytes (MY4), B lymphocytes (B1), and natural killer cells (3G8) for $30 \mathrm{~min}$ on ice. After two washes in PBE, cells were incubated with magnetic microbeads conjugated to rat anti-mouse IgG1 and IgG2a + 2b (MACS; Milteyni Biotec, Sunnyvale, CA) for $30 \mathrm{~min}$ on ice and then passed over a magnetic column. Immunofluorescence flow cytometry showed the purified $\mathrm{T}$ lymphocyte preparations to contain $>95 \% \mathrm{~T}$ lymphocytes $\left(\mathrm{CD}^{+}\right)$and $<1 \%$ monocytes $\left(\mathrm{CD} 14^{+}\right)$, B lymphocytes $\left(\mathrm{CD} 20^{+}\right)$, or natural killer $\left(\mathrm{CD}^{+} 6^{+}\right)$cells. The presence of platelets associated with lymphocytes was evaluated using $\mathrm{mAb}$ to CD41 and P-selectin and was undetectable. T lymphocytes purified in this manner had $>95 \%$ cell viability as determined by trypan blue exclusion and were used in assays within $6 \mathrm{~h}$ of purification. After isolation, the cells were stored in Hanks' balanced salt solution (HBSS; Gibco Laboratories, Grand Island, NY) supplemented with $10 \mathrm{mM}$ Hepes, $1.0 \mathrm{mM} \mathrm{MgCl}_{2}$, and $5 \mathrm{mM}$ EGTA, pH 7.4.

Platelet binding to glass slides. Glass slides $(75 \times 50 \mathrm{~mm}$; Coming Glass Co., Corning, NY) were soaked over night in a chromic-sulfuric acid cleaning solution (Fisher Scientific, Fair Lawn, NJ) and then rinsed with distilled water for $4 \mathrm{~h}$. The slides were dried with anhydrous acetone and immersed once in a $4 \%$ solution of 3-aminopropylthriethoxysilane (Sigma Immunochemicals) in acetone for $2 \mathrm{~min}(40)$. Then, the slides were rinsed once with acetone, washed with distilled water, and dried for $2 \mathrm{~h}$ at $100^{\circ} \mathrm{C}$ Platelets were purified from the same donor as used in $\mathrm{T}$ cell isolation.
Briefly, platelet-rich plasma was centrifuged at $800 \mathrm{~g}$ for $5 \mathrm{~min}$ at $37^{\circ} \mathrm{C}$ and washed twice in Hepes buffer containing $1 \%$ HSA. The platelets were diluted to $5 \times 10^{8}$ cells $/ \mathrm{ml}$ in the same buffer, and $200 \mu \mathrm{l}$ was aliquoted onto the surface of the glass slides. Platelets were allowed to settle for $30 \mathrm{~min}$ at $37^{\circ} \mathrm{C}$ before rinsing and incubating the slides with buffer for $30 \mathrm{~min}$ at $37^{\circ} \mathrm{C}$ to block nonspecific interactions. The platelets were then stimulated with 1 $\mathrm{U} / \mathrm{ml}$ of human thrombin for $2 \mathrm{~min}$ before use in the flow chamber. A confluent layer of spread platelets was formed and confirmed by light microscopy for each experiment.

Detachment assays. A glass slide containing adherent platelets was assembled in a parallel-plate laminar flow chamber (260- $\mu \mathrm{m}$ gap thickness) in which a uniform wall shear stress is generated (8). The flow chamber was mounted on the stage of an inverted phase-contrast microscope (Diaphot-TMD; Nikon Inc., Garden City, NY). To determine the contribution of $\beta_{2}$-integrins of $\mathrm{T}$ cells to adhesion to platelets, all experiments were performed in the presence of $5 \mathrm{mM}$ EGTA and 2.0 $\mathrm{mM} \mathrm{MgCl}{ }_{2} . \beta_{2}$-Integrin/ICAM interactions have been shown to be $\mathrm{Mg}^{2+}$ dependent unlike the $\mathrm{Ca}^{2+}$-dependent selectin interactions (41). $\mathrm{T}$ cells $\left(2 \times 10^{6}\right.$ cells $)$ were injected through a side port and allowed to settle for $6 \mathrm{~min}$. Controlled flow for $20 \mathrm{~s}$ at a shear force of 0.73 $\mathrm{dyn} / \mathrm{cm}^{2}$ was applied, and the number of adherent cells was counted by microscopic observation. All experiments were recorded on videotapes and were performed in duplicate on three separate days. For activation studies, T cells were treated with PMA ( $50 \mathrm{ng} / \mathrm{ml}$, final concentration) for $2 \mathrm{~min}$ before injection into the flow chamber. For antibody inhibition studies, $\mathrm{T}$ cells or adherent platelets were incubated with $20 \mu \mathrm{g} / \mathrm{ml}$ of $\mathrm{mAb}$ for $30 \mathrm{~min}$ at RT before the detachment assay.

\section{Results}

Immunofluorescence flow cytometry of platelets. Flow cytometry showed that ICAM-2 but not ICAM-1 or ICAM-3 is expressed on the surface of platelets (Fig. $1, A-F$ ). Platelet activation with thrombin resulted in no significant increase in expression of ICAM-2 as shown consistently in five separate experiments. By contrast, P-selectin (CD62P) is translocated

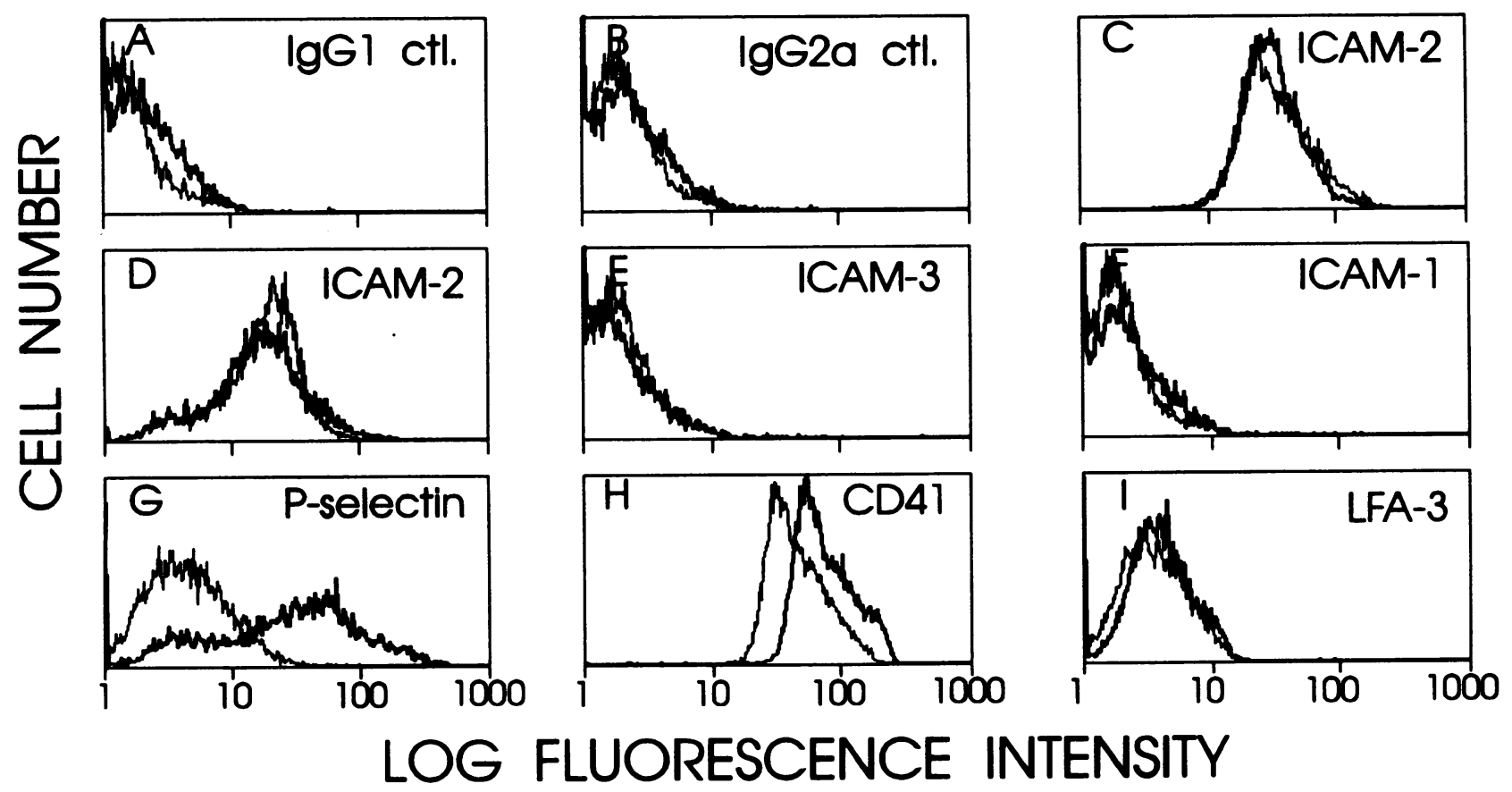

Figure 1. Flow cytometry of platelets. Paraformaldehyde fixed resting (light line) and stimulated (bold line) platelets were incubated with isotype controls $(A, B)$ or mAb to the indicated antigens $(C-I)$. mAbs to ICAM-2 were CBR-IC2/2 $(C)$ and CBR-IC $2 / 1(D)$. 


\section{$\begin{array}{llll}1 & 2 & 3 & 4\end{array}$}

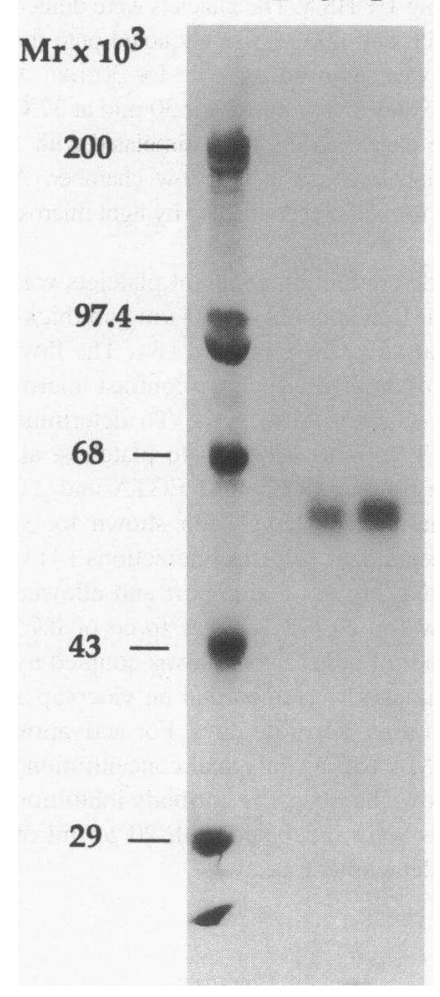

Figure 2. Immunoprecipitation of ICAM-2. Lysates from ${ }^{125} \mathrm{I}$ labeled SKW3 cells (lane 3 ) and resting platelets (lanes 2 and 4 ) were immunoprecipitated with the $\mathrm{mAb}$ CBR-IC2/2 to ICAM2 (lanes 3 and 4 ) or a nonbinding control mAb (lane 2). Material was heated in SDS sample buffer with $5 \% \beta$-mercaptoethanol at $100^{\circ} \mathrm{C}$ and subjected to SDS 8\% PAGE and radiography with enhancing screens. Molecular weight standards are shown in lane 1 . to the surface of platelets upon activation as described previously (Fig. $1 G$ ). ICAM-2 was expressed substantially higher, by about $1 \log$, than the immunoglobulin superfamily adhesion molecule, LFA-3 (CD58) (Fig. 1). Surface expression of ICAM-2 was lower than gpIIbIIIa (CD41) and P-selectin on activated platelets (Fig. 1). Unfixed resting and stimulated platelets gave similar results to fixed cells.

Biochemical characterization of ICAM-2. Immunoprecipitation of ICAM-2 from ${ }^{125} \mathrm{I}$-surface-labeled platelet lysates revealed that it was $59,000 M_{\mathrm{r}}$ under reducing conditions (Fig. 2, lane 4). ICAM-2 from platelets comigrated with ICAM-2 immunoprecipitated from the T lymphoblastoid cell line, SKW3 (Fig. 2, lane 3). mAb to ICAM-1 failed to immunoprecipitate any labeled material from the platelet lysate (data not shown).

Site density determination. Binding of ${ }^{125} \mathrm{I}$-labeled ICAM$2 \mathrm{mAb}$ to platelets was saturable (Fig. 3). Scatchard analysis (Fig. 3, inset) indicated a single class of antibody-binding sites on the platelet surface, with a $K_{\mathrm{d}}$ of $4.7 \mathrm{nM}$. Equivalent results were obtained with activated platelets (data not shown). The average number of binding sites per platelet is $2,960 \pm 256$ for resting and 3,048 \pm 325 for stimulated platelets. These data, as well as those obtained in flow cytometry, demonstrate that ICAM-2 is constitutively expressed on the surface of platelets.

Immunocytochemistry. Expression of ICAMs on bone marrow cells was examined on smears stained with ICAM-1, ICAM-2, or ICAM-3 mAb and APAAP immunohistochemistry. At a 1:500 dilution of the ICAM-2 mAb $(5.3 \mu \mathrm{g} / \mathrm{ml})$, a brilliant red staining was observed for most megakaryocytes (Fig. $4 a$ ) and in spicules of marrow which contain clumps of endothelial cells (not shown). At dilutions of 1:50 and 1:100, but not at

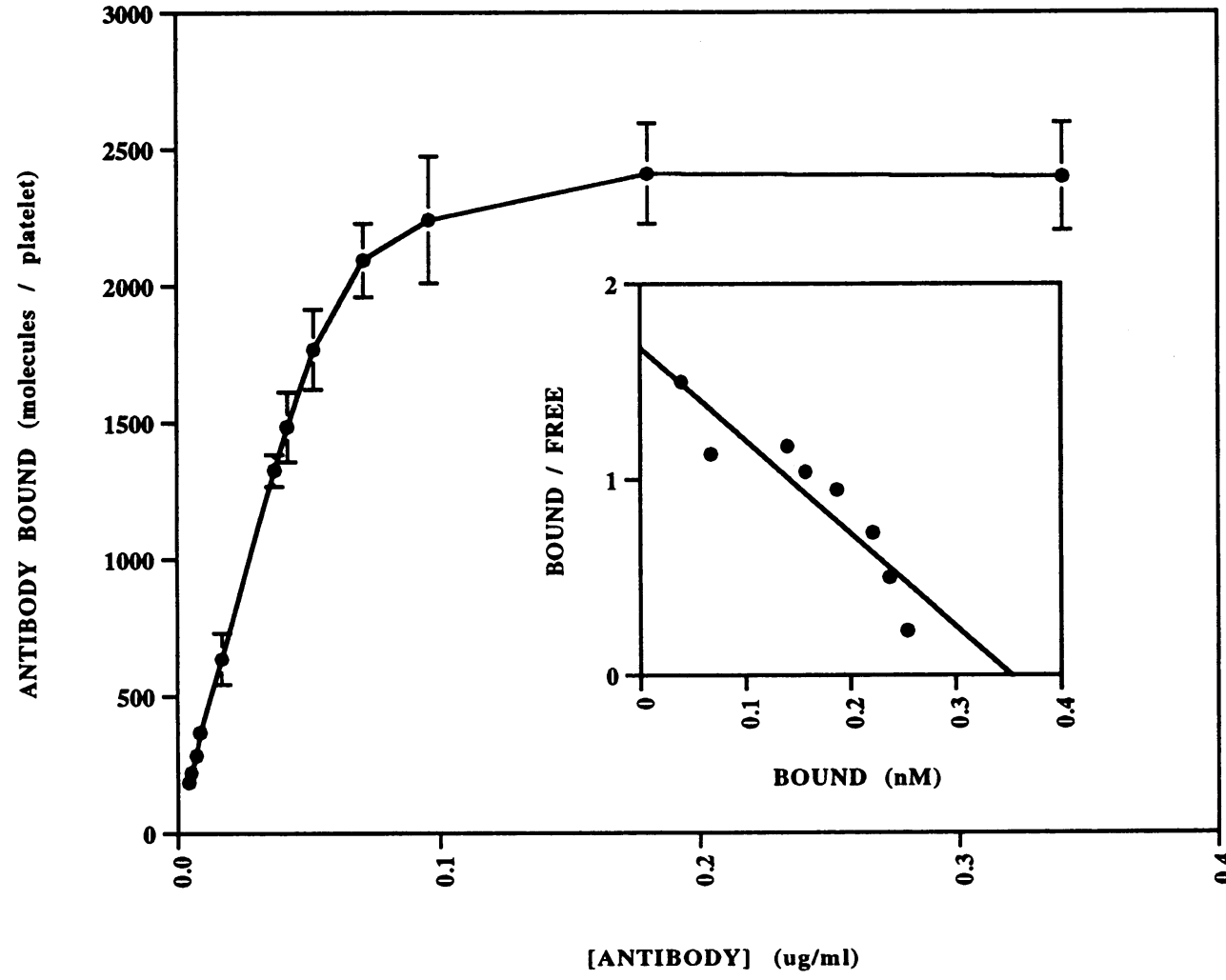

Figure 3. Saturation binding of ${ }^{125}$ I-labeled ICAM-2 mAb to resting platelets. Platelets were incubated with the indicated concentration of ICAM-2 mAb, and bound antibody was measured as described in Methods. Nonspecific binding was determined by incubation with a 100 -fold excess of unlabeled ICAM-2 $\mathrm{mAb}$ and was $<10 \%$ of the specific binding. A Scatchard plot of the data obtained with activated platelets is shown (inset). All experiments were performed in triplicate, and the data shown here are the average of four separate experiments. Bars show the standard deviation. 


\section{CBR-IC2/2}

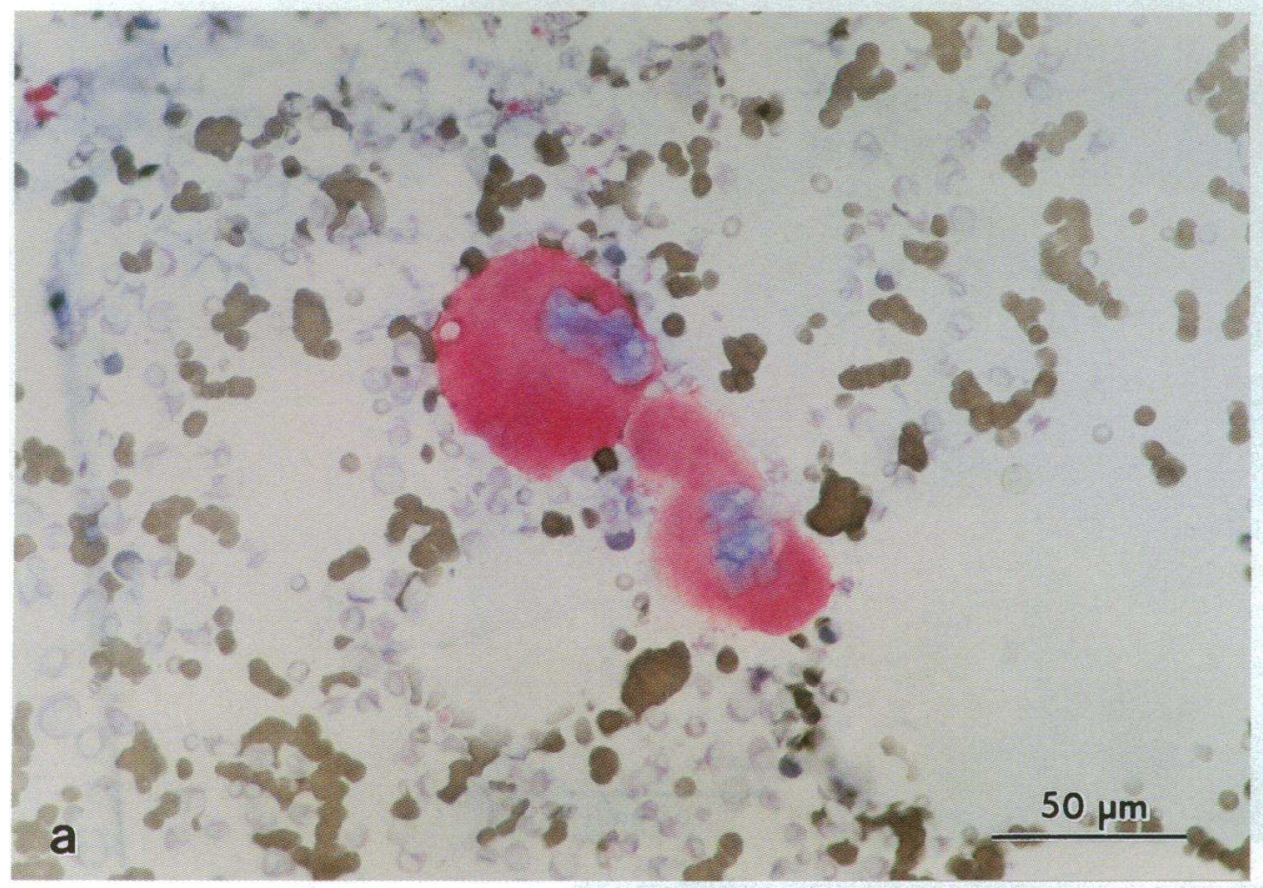

\section{$\mathrm{X} 63$}

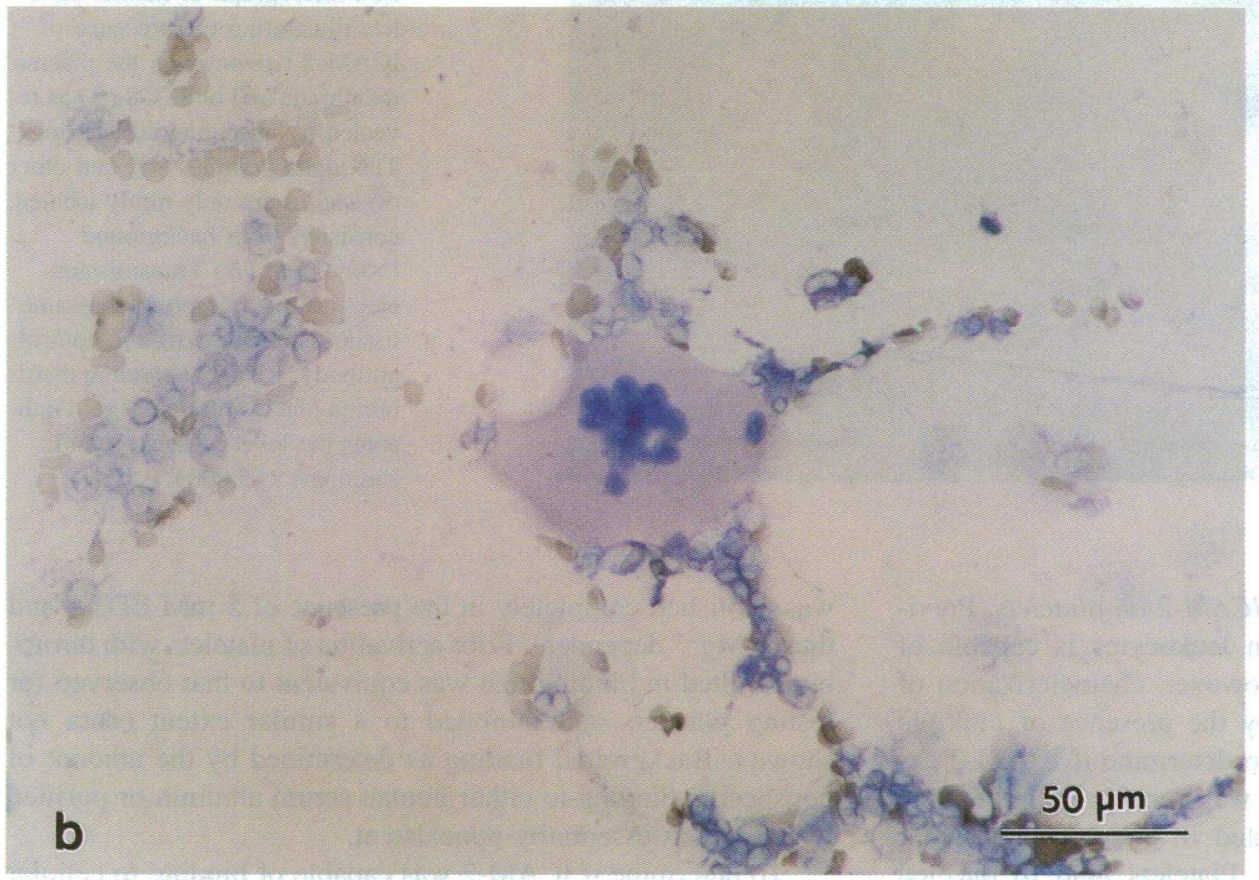

Figure 4. Photomicrographs of human bone marrow smears stained with ICAM-2 $\mathrm{mAb}$ and visualized with APAAP. (a) ICAM-2 mAb. Megakaryocytes are positive for ICAM-2 as indicated by the red reaction product. (b) Nonbinding control X63 mAb. No staining was observed. A megakaryocyte is in the center of the field. $\times 400$.
1:500, developing and mature neutrophils, but not eosinophils, were also stained (not illustrated). No staining of megakaryocytes was observed with mAb to either ICAM-1 or ICAM-3 (data not shown). The control $\mathrm{mAb}, \mathrm{X63}$, did not reveal any nonspecific staining of cells (Fig. $4 b$ ).

Subcellular localization of ICAM- 2 was evaluated by using an immunogold procedure on frozen thin sections of resting platelets. Immunogold label was evident not only on the plasma membrane, but also along the membrane of the surface connected canalicular system (SCCS) (Fig. 5). Other organelles were not labeled above background. When the control $\mathrm{mAb}$ X63 was used, labeling was rare (Fig. 5 B). 

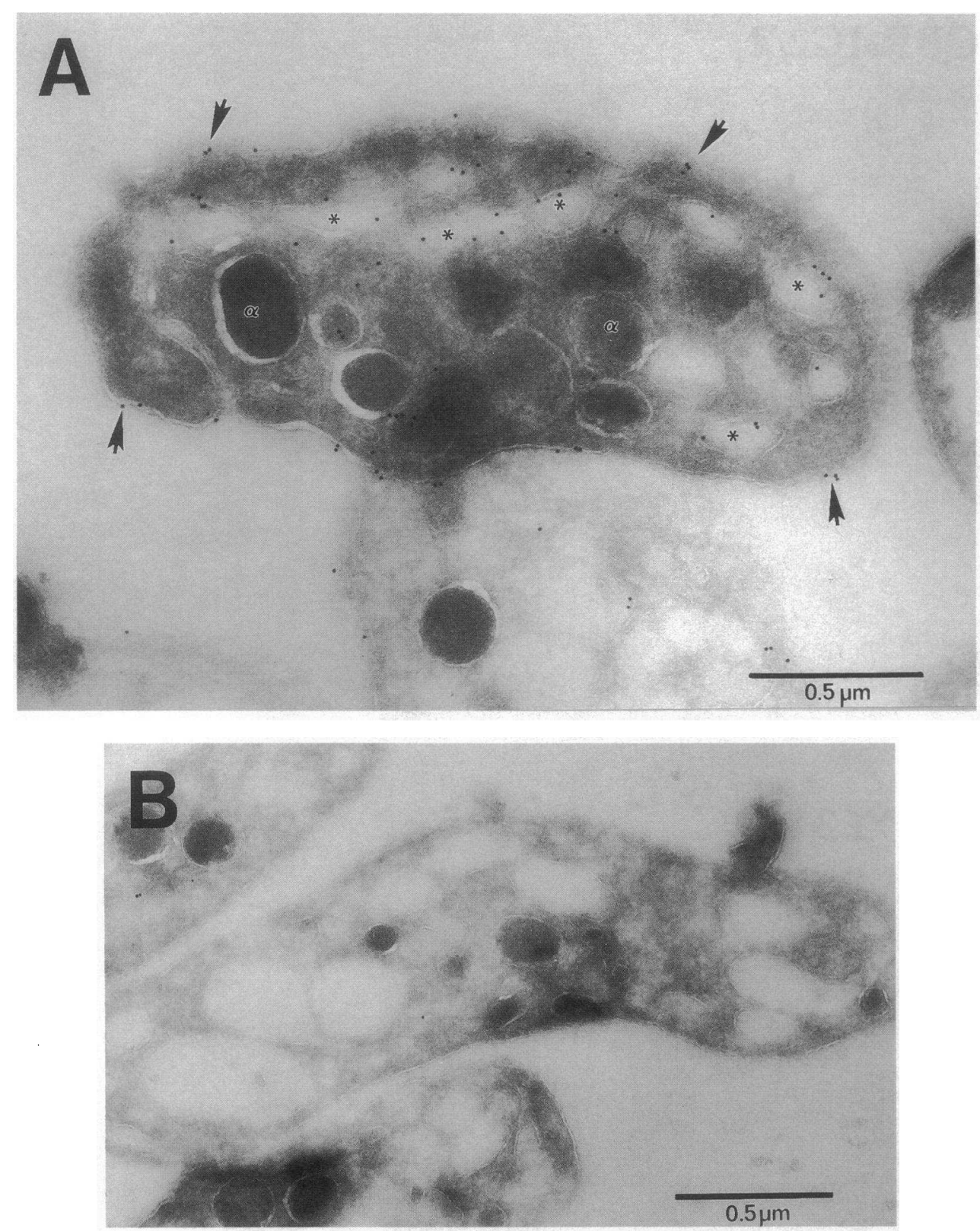

Figure 5. (A) Transmission electron micrograph of human platelets illustrating the presence of ICAM-2 (arrows) on the plasma membrane and in SCCS $(*)$ as revealed by immunogold labeling. The alpha granules $(\alpha)$ and other organelles are only rarely labeled, consistent with background $(\times 65,000)$. (B) Transmission electron micrograph of the same tissue incubated with the control antibody, $\times 63$. The random distribution of a few grains of gold indicates the level of background staining $(\times 45,000)$.

Functional characterization of ICAM-2 on platelets. Previous studies suggest that LFA-1 on leukocytes is capable of binding to a ligand on platelets. However, characterization of these interactions is complicated by the presence of multiple adhesion receptors on both cells. To determine if ICAM- 2 expressed on the surface of platelets was capable of interacting with LFA-1, platelets were incubated in plates or microtiter wells coated with purified LFA-1. Platelets bind to purified LFA-1 (Figs. 6, $a$ and $b$, and 7). Similar binding was seen in the presence of control mAb TP1/15 (anti-CD31), in the absence of this $\mathrm{mAb}$, or if mAb to ICAM-1 or ICAM-3 was preincubated with platelets (data not shown). This interaction was almost completely inhibited by mAbs to ICAM-2 or LFA1 (Figs. 6, $c$ and $d$, and 7). The equal inhibition by mAb to ICAM-2 and LFA-1 suggests that ICAM-2 is the only ligand on platelets for LFA-1. Binding in the presence of $2 \mathrm{mM} \mathrm{Mg} \mathrm{Mg}^{2+}$ was abolished completely in the presence of $5 \mathrm{mM}$ EDTA and thus is $\mathrm{Mg}^{2+}$ dependent. Prior activation of platelets with thrombin resulted in binding that was equivalent to that observed for resting platelets and inhibited to a similar extent (data not shown). Background binding as determined by the amount of nonspecific binding to either human serum albumin or purified ICAM-1 was essentially nonexistent.

To determine if ICAM-2 was capable of binding to cellular LFA-1, purified T cells were allowed to settle on platelet-coated glass slides for $6 \mathrm{~min}$ and then were subjected to shear flow at $0.73 \mathrm{dyn} / \mathrm{cm}^{2}$. Binding was carried out in the presence of EGTA and $\mathrm{Mg}^{2+}$ to isolate integrin-dependent interactions from those dependent on selectins. PMA stimulation of the T lymphocytes greatly augmented (about fourfold) the binding to platelets (Fig. 8). Lymphocytes were firmly attached to the platelets, i.e., they did not roll. Essentially all of the PMA-stimulated 

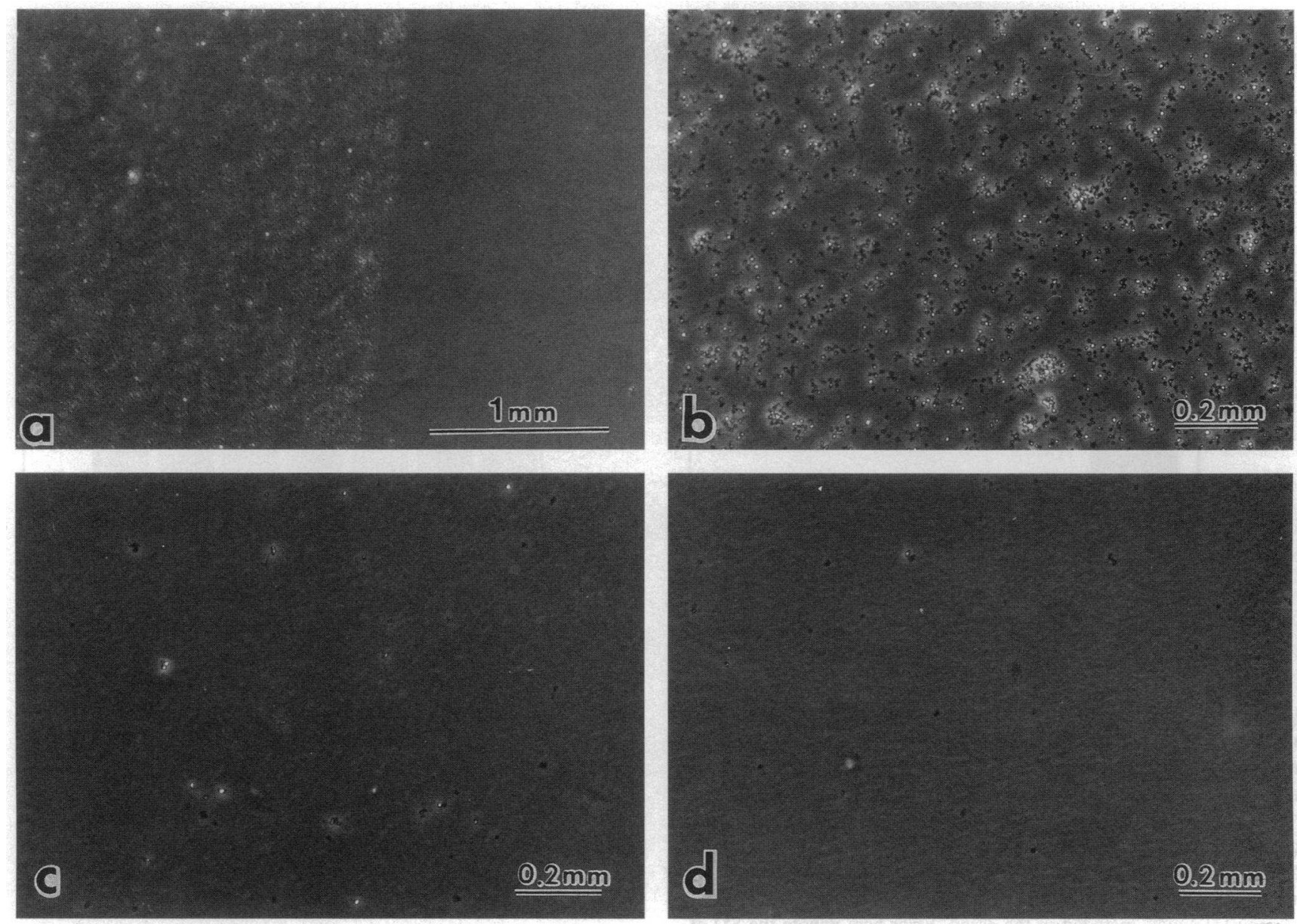

Figure 6. Photomicrographs of gel-filtered platelets binding to LFA-1-coated plastic Petri dishes in the presences of: $(a$ and $b)$ control mAb; $(c)$ anti-ICAM-2 mAb (CBR-IC2/2); $(d)$ anti-LFA-1 $\alpha$ chain mAb (TS1/22) $(\times 25[a], \times 60[b-d]$. In $a$, the border of the LFA-1-coated spot on the Petri dish is shown.

binding was inhibited by mAb to ICAM-2 and LFA-1. Inhibition by mAb to LFA-1 and ICAM-2 was equal, and mAb to ICAM-1 and ICAM-3 had no effect, suggesting that ICAM-2 is the only ligand on platelets recognized by LFA-1. All binding was abolished in the presence of EDTA demonstrating dependence on $\mathrm{Mg}^{2+}$. When unstimulated lymphocytes were allowed to settle on platelet-coated glass slides in the presence of $\mathrm{Mg}^{2+}$ and $\mathrm{Ca}^{2+}$, a similar number of lymphocytes formed rolling adhesions as compared with the PMA-induced firm attachments described above; the former were abolished by treatment with $\mathrm{mAb}$ to P-selectin (data not shown).

\section{Discussion}

This study demonstrates that ICAM-2 is expressed on the surface of resting and thrombin-activated platelets. ICAM-2 is the only currently known cell-surface integrin ligand expressed on platelets. Activation of platelets resulted in no change in surface expression of ICAM-2 as determined by flow cytometry and saturation binding with $\mathrm{mAb}$. The constitutive expression of this adhesion molecule on platelets is analogous to its constitutive expression on endothelium (13). This is in contrast to P-selectin, which is rapidly translocated to the surface of platelets upon activation. Immunohistochemistry and immunogold electron microscopy showed that ICAM-2 is expressed in bone marrow on megakaryocytes and in platelets is restricted to the plasma membrane and SCCS. ICAM-2 from platelets migrates as a band of $59,000 M_{\mathrm{r}}$ in SDS-PAGE under reducing conditions, identical to ICAM-2 isolated from the T cell line SKW3. The average number of ICAM-2 binding sites per platelet is 3,000. ICAM-2 expressed on platelets is functional, since it supports adhesion to purified and cellular LFA-1. This interaction is specifically inhibited by mAb to either ICAM-2 or LFA-1 and was $\mathrm{Mg}^{2+}$ dependent.

ICAM-2 is the only ligand on platelets for LFA-1, as shown by equal inhibition by mAb to LFA-1 and ICAM-2 of platelet binding to purified LFA-1 and of T lymphocyte binding to platelet monolayers. Furthermore, mAbs to ICAM-1 or ICAM3 have no effect on either assay.

When lymphocytes adherent to platelets through the LFA1/ICAM-2 interaction were subjected to shear flow, they did not roll, showing that firm attachments had developed. Lymphocyte interaction with platelets through P-selectin is similar in binding efficiency in the same assay system, but permits rolling when the cells are subjected to shear flow (data not shown). Interaction with $\mathrm{P}$-selectin requires $\mathrm{Ca}^{2+}$ and does not require PMA 


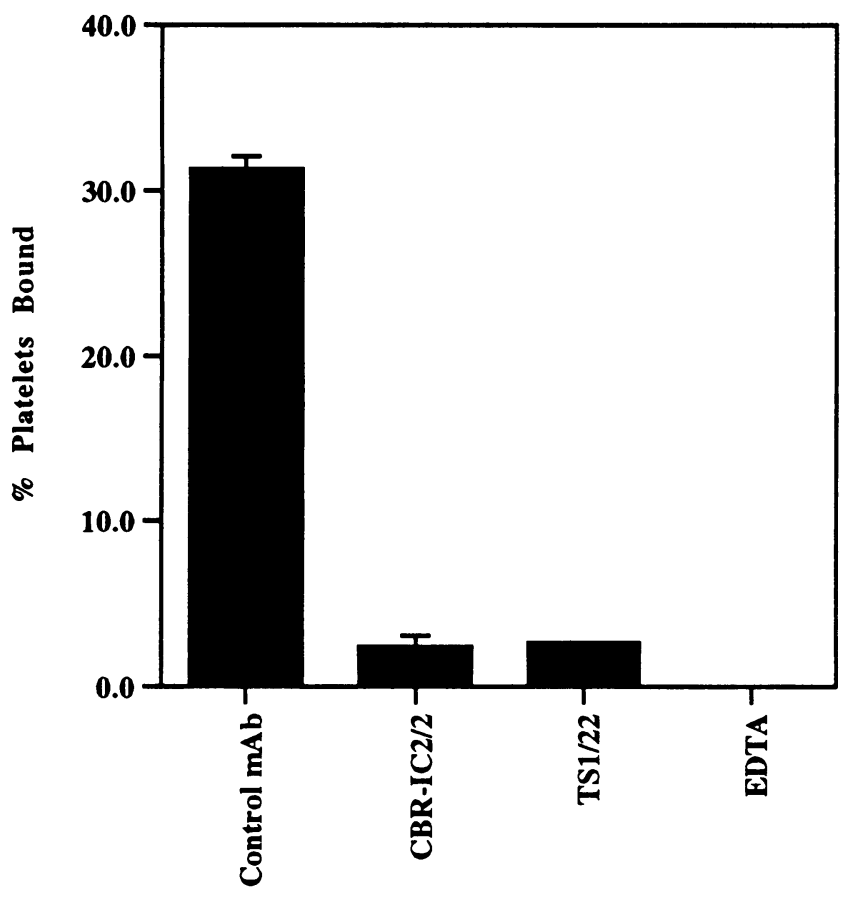

Figure 7. Quantitation of platelet binding to LFA-1. 2',7'-bis-(2-carboxyethyl) -5 (and 6 ) carboxyfluorescein-labeled platelets were incubated on LFA-1-coated microtiter wells for $30 \mathrm{~min}$ at $37^{\circ} \mathrm{C}$ and then washed eight times by aspiration. Results are expressed as the percentage of platelets remaining after the washes. Before binding, platelets were incubated with saturating concentrations of control mAb 7E1 (antiCD31) or mAb CBR-IC2/2 (anti-ICAM-2). Alternatively, the absorbed purified LFA-1 was pretreated with mAb TS1/22 (anti-LFA$1 \alpha)$, or EDTA was included in the assay. Error bars denote the SD of triplicates in one representative experiment.

stimulation of the lymphocytes, in contrast to the LFA-1/ ICAM-2 interaction.

ICAM-2 is a member of the immunoglobulin superfamily of adhesion molecules (42). ICAM-2 is constitutively expressed at high levels on endothelial cells (13). On resting endothelial cells, its level is estimated to be 10-15-fold higher than the cytokine-inducible adhesion molecule, ICAM-1. ICAM-2 is the most prominent LFA- 1 ligand on resting endothelia and a candidate for facilitating basal extravasation of lymphocytes and monocytes (13). The important interactions between $\beta_{2}$-integrins and ICAM- 1 and ICAM-2 in adherence and subsequent transmigration of leukocytes across endothelial cells have been well characterized $(43,44)$. ICAM- 2 on platelets may serve a similar function. The adherence of platelets to damaged endothelium and subsequent rapid expression of P-selectin would result in the recruitment of leukocytes to such areas $(45,46)$. P-selectin-mediated adhesion would result in the tethering of leukocytes to activated platelets (step 1). This would allow for subsequent local leukocyte activation and upregulation of leukocyte surface integrins such as LFA-1 ( step 2). We have demonstrated in this report that stabilization of platelet-leukocyte adhesion, step 3 in the adhesion cascade, can be mediated by the LFA-1/ICAM-2 interaction. LFA-1 and ICAM-2 may also participate in other functionally important interactions between leukocytes and platelets, such as transcellular leukotriene synthesis and elevation by activated platelets of superoxide

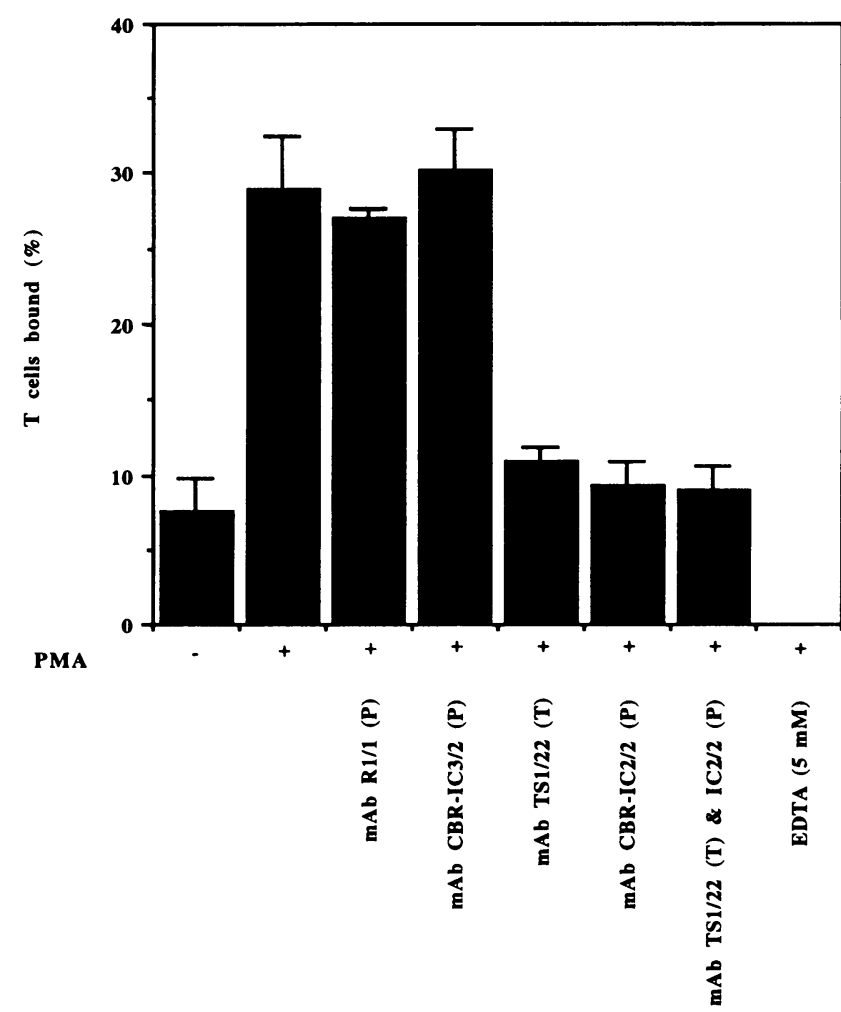

Figure 8. Detachment assay after static incubation of $\mathrm{T}$ cells on platelets in the presence of EGTA and $\mathrm{MgCl}_{2}$. T cells were injected into the flow chamber and allowed to settle. After 6 min of contact, a shear of $0.73 \mathrm{dyn} / \mathrm{cm}^{2}$ was applied. T cells remaining bound after $20 \mathrm{~s}$ of flow are expressed as the percentage of cells that settled in the initial contact period. For six of the experiments. PMA was added to the T cell suspension before it was injected into the flow chamber $(+)$. Antibody inhibition studies consisted of incubating the adherent platelets $(P)$ or T cells $(T)$ with mAb as indicated. Error bars represent the SD of three to six independent experiments.

anion production $(47,48)$. Thus, the interaction between LFA1 and ICAM-2 may have significant clinical consequences in the facilitation of inflammatory and hemostatic processes at sites of vascular injury.

\section{Acknowledgments}

We thank Dr. T. Kovacsovics for instruction in platelet purification techniques. Mr. E. Luther for flow cytometry analysis, and Yvonne Jacques for electron microscopy analysis.

This work was supported by National Institutes of Health grants CA-31798 and HLB 31610.

\section{References}

1. Smyth. S. S.. C. C. Joneckis. and L. V. Parise. 1993. Regulation of vascular integrins. Blood. 81:2827-2843.

2. Ginsberg. M. H.. J. C. Loftus, and E. F. Plow. 1988. Cytoadhesins, integrins, and platelets. Thromb. Haemost. 59:1-6.

3. Kieffer. N.. and D. R. Phillips. 1990. Platelet membrane glycoproteins: Functions in cellular interactions. Annu. Rev. Cell Biol. 6:329-357.

4. Hynes, R. O. 1991. The complexity of platelet adhesion to extracellular matrices. Thromb. Haemost. 66:40-43.

5. Stenberg. P. E., R. P. McEver. M. A. Shuman. Y. V. Jacques, and D. F. 
Bainton. 1985. A platelet alpha granule membrane protein (GMP-140) is expressed on the plasma membrane after activation. J. Cell Biol. 101:880-886.

6. Hsu-Lin, S. -C., C. L. Berman, B. C. Furie, D. August, and B. Furie. 1984 A platelet membrane protein expressed during platelet activation and secretion Studies using a monoclonal antibody specific for thrombin-activated platelets. $J$. Biol. Chem. 259:9121-9126.

7. Mayadas, T. N., R. C. Johnson, H. Rayburn, R. O. Hynes, and D. D. Wagner. 1993. Leukocyte rolling and extravasation are severely compromised in P-selectin-deficient mice. Cell. 74:541-554.

8. Lawrence, M. B., and T. A. Springer. 1991. Leukocytes roll on a selectin at physiologic flow rates: distinction from and prerequisite for adhesion through integrins. Cell. 65:859-873.

9. Snyderman, R., and R. J. Uhing. 1992. Chemoattractant stimulus-response coupling. In Inflammation: Basic Principles and Clinical Correlates. J. I. Gallin,

I. M. Goldstein, and R. Snyderman, editors. Raven Press, New York. 421-439.

10. Miller, M. D., and M. S. Krangel. 1992. Biology and biochemistry of the chemokines: a family of chemotactic and inflammatory cytokines. Crit. Rev. Immunol. 12:17-46.

11. McEver, R. P. 1991. GMP-140: A receptor for neutrophils and monocytes on activated platelets and endothelium. J. Cell. Biochem. 45:156-161.

12. Hymes, K., M. Nardi, A. Leaf, and S. Karpatkin. 1993. Role of LeuCAM integrins and complement in platelet-monocyte rosette formation induced by immune complexes of human immunodeficiency virus-type 1-immune thrombocytopenic purpura patients. Blood. 81:2375-2380.

13. deFougerolles, A. R., S. A. Stacker, R. Schwarting, and T. A. Springer 1991. Characterization of ICAM-2 and evidence for a third counter-receptor for LFA-1. J. Exp. Med. 174:253-267.

14. Timmons, S., and J. Hawiger. 1978. Separation of human platelets from plasma proteins including factor VIII $\mathrm{VWF}_{\mathrm{WW}}$ by a combined albumin gradient-gel filtration method using hepes buffer. Thromb. Res. 12:297-306.

15. Rothlein, R., M. L. Dustin, S. D. Marlin, and T. A. Springer. 1986. A human intercellular adhesion molecule (ICAM-1) distinct from LFA-1. J. Immunol. 137:1270-1274.

16. deFougerolles, A. R., and T. A. Springer. 1992. Intercellular adhesion molecule 3, a third adhesion counter-receptor for lymphocyte function-associated molecule 1 on resting lymphocytes. J. Exp. Med. 175:185-190.

17. Sanchez-Madrid, F., A. M. Krensky, C. F. Ware, E. Robbins, J. L. Strominger, S. J. Burakoff, and T. A. Springer. 1982. Three distinct antigens associated with human T lymphocyte-mediated cytolysis: LFA-1, LFA-2, and LFA-3. Proc. Natl. Acad. Sci USA 79:7489-7493.

18. Vonderheide, R. H., T. F. Tedder, T. A. Springer, and D. E. Staunton. 1993. Residues within a conserved amino acid motif of domains 1 and 4 of VCAM-1 are required for binding to VLA-4. J. Cell Biol. 125:215-222.

19. Griffin, J. D., J. Ritz, L. M. Nadler, and S. F. Schlossman. 1981. Expression of myeloid differentiation antigens on normal and malignant myeloid cells. $J$. Clin. Invest. 69:932-941.

20. Reinherz, E. L., and S. F. Schlossman. 1980. The differentiation and function of human T lymphocytes. Cell. 19:821-827.

21. Fleit, H. B., M. Kuhnle, and C. D. Kobasiuk. 1989. Monoclonal antibodie to $\mathrm{CD} 16$ detect antigenic differences in $\mathrm{Fc}$ gamma RIII on neutrophils and natura killer cells. In Leucocyte Typing IV: White Cell Differentiation Antigens. W Knapp, B. Dorken, W. R. Gilks, E. P. Rieber, R. E. Schmidt, H. Stein, and A. E. G. Kr. von dem Borne, editors. Oxford University Press, Oxford. 579-581. 22. Coller, B. S. 1985. A new murine monoclonal antibody reports an activation-dependent change in the conformation and/or microenvironment of the platelet glycoprotein IIb/IIIa complex. J. Clin. Invest. 76:101-108.

23. McEver, R. P., and M. N. Martin. 1984. A monoclonal antibody to a membrane glycoprotein binds only to activated platelets. J. Biol. Chem. 259:9799-9804.

24. Yelton, D. E., C. Desaymard, and M. D. Scharff. 1981. Use of monoclonal anti-mouse immunoglobulin to detect mouse antibodies. Hybridoma. 1:5-11.

25. Tuszynski, G. P., L. C. Knight, E. Kornecki, and S. Srivastava. 1983. Labeling of platelet surface proteins with ${ }^{125} \mathrm{I}$ by the iodogen method. Anal. Biochem. 130:166-170.

26. Kessler, S. W. 1975. Rapid isolation of antigens from cells with a staphylo- coccal protein A-antibody adsorbent: Parameters of the interaction of antibodyantigen complexes with protein A. J. Immunol. 115:1617.

27. Laemmli, U. K., and M. Favre. 1973. Maturation of the head of bacteriophage T4. J. Mol. Biol. 80:575-599.

28. Fraker, P. J., and J. C. Speck. 1978. Protein and cell membrane iodinations with a sparingly soluble chloroamide, 1,3,4,6-tetrachloro-3,6-diphenyl glycoluril. Biochem. Biophys. Res. Commun. 80:849-857.

29. Nesheim, M. E., D. D. Pittman, J. H. Wang, D. Slonosky, A. R. Giles, and R. J. Kaufman. 1988. The binding of ${ }^{35} \mathrm{~S}$-labeled recombinant factor VIII to activated and unactivated human platelets. J. Biol. Chem. 263:16467-16470.

30. Scatchard, G. 1949. The attractions of proteins for small molecules and ions. Ann. NY Acad. Sci. 51:660-672.

31. McLean, I. W., and P. K. Nakane. 1974. Periodate-lysine-paraformaldehyde fixative: a new fixative for immunoelectron microscopy. J. Histochem. Cytochem. 22:1077-1083.

32. Stenberg, P. E., M. A. Shuman, S. P. Levine, and D. F. Bainton. 1984 Optimal techniques for the immunocytochemical demonstration of $\beta$-thromboglobulin, platelet factor 4 , and fibrinogen in the alpha granules of unstimulated platelets. Histochem. J. 16:983-1001.

33. Bainton, D. F., L. J. Miller, T. K. Kishimoto, and T. A. Springer. 1987. Leukocyte adhesion receptors are stored in peroxidase-negative granules of human neutrophils. J. Exp. Med. 166:1641-1653.

34. Tokuyasu, K. T. 1983. Present state of immunocryoultramicrotomy. J. Histochem. Cytochem. 31:164.

35. Griffiths, G., A. McDowall, R. Back, and J. Dubochet. 1984. On the preparation of cryosections for immunocytochemistry. J. Ultrastruc. Res. 89:65.

36. Dustin, M. L., and T. A. Springer. 1989. T cell receptor cross-linking transiently stimulates adhesiveness through LFA-1. Nature (Lond.). 341:619624

37. Miller, L. J., D. F. Bainton, N. Borregaard, and T. A. Springer. 1987 Stimulated mobilization of monocyte Mac-1 and p150,95 adhesion proteins from an intracellular vesicular compartment to the cell surface. J. Clin. Invest. 80:535544.

38. Miltenyi, S., W. Muller, W. Weichel, and A. Radbruch. 1990. High gradient magnetic cell separation with MACS. Cytometry. 11:231-238.

39. Abts, H., M. Emmerich, S. Miltenyi, A. Radbruch, and H. Tesch. 1989. CD20 positive human B lymphocytes separated with the magnetic cell sorter (MACS) can be induced to proliferation and antibody secretion in vitro. J. Immunol. Methods. 125:19-28.

40. Buttrum, S. M., R. Hatton, and G. B. Nash. 1993. Selectin-mediated rolling of neutrophils on immobilized platelets. Blood. 82:1165-1174.

41. Marlin, S. D., and T. A. Springer. 1987. Purified intercellular adhesion molecule-1 (ICAM-1) is a ligand for lymphocyte function-associated antigen 1 (LFA-1). Cell. 51:813-819.

42. Staunton, D. E., M. L. Dustin, and T. A. Springer. 1989. Functional cloning of ICAM-2, a cell adhesion ligand for LFA-1 homologous to ICAM-1. Nature (Lond.). 339:61-64.

43. Springer, T. A. 1994. Traffic signals for lymphocyte recirculation and leukocyte emigration: the multi-step paradigm. Cell. 76:301-314.

44. Springer, T. A. 1990 . Adhesion receptors of the immune system. Nature (Lond.). 346:425-433.

45. Palabrica, T., R. Lobb, B. C. Furie, M. Aronovitz, C. Benjamin, Y. Hsu, S. A. Sajer, and S. Furie. 1992. Leukocyte accumulation promoting fibrin deposition is mediated in vivo by P-selectin on adherent platelets. Nature (Lond.). $359: 848-851$.

46. Bednar, M., B. Smith, A. Pinto, and K. M. Mullane. 1985. Neutrophil depletion suppresses "IIIn-labeled platelet accumulation in infarcted myocardiu. J. Cardiovasc. Pharmacol. 7:906-912.

47. Maclouf, J. A., and R. C. Murphy. 1988. Transcellular metabolism of neutrophil-derived leukotriene $\mathrm{A}_{4}$ by human platelets. J. Biol. Chem. 263:174181.

48. Nagata, K., T. Tsuji, N. Todoroki, Y. Katagiri, K. Tanoue, H. Yamazaki, $\mathrm{N}$. Hanai, and T. Irimura. 1993. Activated platelets induce superoxide anion release by monocytes and neutrophils through P-selectin (CD62). J. Immunol. $151: 3267-3273$ 